\title{
Russian Language
}

National Cancer Institute

\section{Source}

National Cancer Institute. Russian Language. NCI Thesaurus. Code C123790.

An East Slavic language spoken as an official language in Russia, Belarus, Kazakhstan, and Kyrgyzstan. 